\section{Seed Production and Viability of Eight Porterweed Selections Grown in Northern and Southern Florida}

\author{
Sandra B. Wilson ${ }^{1}$ \\ Indian River Research and Education Center, Fort Pierce, FL 34945
}

Gary W. Knox

North Florida Research and Education Center, 155 Research Road, Quincy, FL 32351

Keona L. Muller

Indian River Research and Education Center, Fort Pierce, FL 34945

Rosanna Freyre

P.O. Box 110670, Gainesville, FL 32611

\section{Zhanao Deng \\ Gulf Coast Research and Education Center, 14625 CR 672, Wimauma, FL 33598}

Additional index words. invasive, native, cultivar trialing, flow cytometry, seed germination, Stachytarpheta jamaicensis, Stachytarpheta mutabilis, Stachytarpheta speciosa, Stachytarpheta cayennensis

\begin{abstract}
Nettleleaf porterweed (Stachytarpheta cayennensis) is a potentially invasive ornamental plant in Florida. Plant growth, visual quality, flowering, and seed viability were assessed for nettleleaf porterweed and eight closely related alternatives planted in northern and southern Florida. In northern Florida, 'Mario Pollsa' porterweed (Stachytarpheta spp.), 'Violacea' porterweed (Stachytarpheta mutabilis), 'Naples Lilac' porterweed (Stachytarpheta spp.), 'Red Compact' porterweed (Stachytarpheta speciosa), and nettleleaf porterweed (Stachytarpheta cayennensis) achieved high flower ratings between 4 (average to good flowering) and 5 (abundant flowering, peak bloom) during 4 or more months. Also, jamaican porterweed (Stachytarpheta jamaicensis), 'Violacea' porterweed, 'Red Compact' porterweed, and nettleleaf porterweed achieved visual quality ratings between 4 and 5 (good to excellent quality) throughout most of the study. In southern Florida, the same cultivars received high flower ratings but generally for shorter periods of time. Also, 'Violacea' porterweed and 'Red Compact' porterweed consistently received visual quality ratings that were above 4 (good quality, very desirable). During the course of the 28 -week study, nettleleaf porterweed produced the greatest number of spiked inflorescences with $39 \%$ to $80 \%$ seed viability. At both locations, 'Violacea' porterweed did not produce any viable seed and seed viability was less than $10 \%$ for 'Mario Pollsa' porterweed, coral porterweed (Stachytarpheta mutabilis), and 'Naples Lilac' porterweed.
\end{abstract}

The invasive plant management program in Florida has contracted over 190 research projects at a cost of $\$ 19.8$ million over the last 39 years (Schmitz, 2009). Despite these efforts, plant invasions continue to rise. The State of Florida is the second largest producer of ornamental plants in the United States with

Received for publication 16 July 2009. Accepted for publication 22 Sept. 2009.

Indian River Research and Education Center Journal Series No. R-070901.

We gratefully acknowledge financial support from the Florida Department of Environmental Protection. We extend gratitude to Patricia Frey and James Aldrich for providing field and technical assistance throughout the study.

${ }^{1}$ To whom reprint requests should be addressed; e-mail sbwilson@ufl.edu. detrimental generations later if invasion occurs (Caley et al., 2008). Desirable attributes of nettleleaf porterweed (Stachytarpheta cayennensis) are its long period of profuse and vibrantly colored flowers that attract butterflies and adaptability to a range of landscape conditions; yet a consequence of this is its ability to self-seed and readily naturalize in areas far beyond its planting. Introduced to the United States from Central and South America, nettleleaf porterweed has since escaped cultivation in Florida, Hawaii, and Puerto Rico (U.S. Department of Agriculture, 2008). In Florida, herbarium vouchers document its escape in two of the southern-most counties (Wunderlin and Hansen, 2009a). It has been found in 18 conservation areas in Florida (Gann et al., 2008) and is problematic in other parts of the world, including the Pacific Islands (Pacific Island Ecosystems at Risk, 2007) and Australia (World Wildlife Fund Australia, 2006). In Australia, it was ranked as an environmental weed with a score of 4 , meaning it has naturalized and is known to be a major problem at three or fewer locations within a state or territory (Groves et al., 2005). Florida's Exotic Pest Plant Council (FLEPPC) designates porterweed as a Category II invasive, indicating that it has increased in abundance or frequency but has not yet altered Florida plant communities to the extent shown by Category I species (FLEPPC, 2007). In 2006, The University of Florida Institute of Food and Agricultural Sciences Status Assessment of Non-native Plants (Fox et al., 2008) recommended that porterweed be used with caution and managed to prevent its escape. These conclusions were footnoted to emphasize that there was insufficient evidence to fully validate the statement and that the status should be reassessed every 2 years (Fox et al., 2008).

As alternatives to the resident species (wild-type form) of nettleleaf porterweed, there are several other closely related species that have ornamental value such as coral porterweed (Stachytarpheta mutabilis), 'Violacea' porterweed (Stachytarpheta mutabilis), and several dwarf porterweed selections (Stachytarpheta speciosa) (Caldwell, 2005). In addition, there is a Florida native jamaican porterweed (Stachytarpheta jamaicensis) that is distinctively lower-growing with a more horizontal spread (Gilman, 2007; Hammer, 1994). The genus Stachytarpheta has undergone a series of taxonomic revisions that are further complicated by putative hybrids (Munir, 1992). In Florida, the Category II invasive nettleleaf porterweed reportedly hybridizes with the native jamaican porterweed and is documented as Stachytarpheta $\times$ intercedens (Wunderlin and Hansen, 2009b). In Hawaii, Wagner et al. (1999) report that the hybrid resembles jamaican porterweed more closely than nettleleaf porterweed, but the corollas are darker in color than jamaican porterweed with a more erect habit and more ovate and darker green leaves. Wagner et al. (1999) also report that nettleleaf porterweed hybridizes with coral porterweed. Munir 
(1992) report that $S$. xintercedens actually evolved by the hybridization of indian snakeweed (Stachytarpheta indica) and jamaican porterweed. Hybridization potential between native and invasive species of the same genus is of particular concern. For example, the FLEPPC Category I invasive lantana (Lantana camara) has extensively hybridized with all three distinct varieties of the Florida native pineland lantana (Lantana depressa), contaminating the endemic gene pool (Langeland and Craddock Burks, 1998). Schierenbeck and Ellstrand (2009) have reviewed numerous examples in which hybridization preceded the emergence of successful invasive populations. Controlled plant breeding has been used to develop numerous new noninvasive plants (with improved commercial traits) in several states, including North Carolina (Ranney, 2004), Connecticut ( $\mathrm{Li}$ et al., 2004), and Florida (Czarnecki et al., 2008). Stachytarpheta is a genus of $\approx 133$ species with six species recognized and taxonomically reviewed in Australia (Munir, 1992) and 79 species recognized and infragenerically classified in Brazil (Atkins, 2005). Dwarf and tall cultivars have been selected with flowers displaying various hues of blue, purple, pink, and red. There is a range of polyploids within the porterweed genus and even within some of its species (Sanders, 2001). The magnitude of effort needed to incorporate sterility into new porterweed breeding lines will depend on existing ploidy levels among cultivars. Relatively little is known about the ploidy level, vigor, flowering, and seed viability of cultivars grown in Florida, because they are routinely propagated by vegetative cuttings. The overall objective of this study was to evaluate horticultural attributes and potential invasiveness of the FLEPPC Category II invasive nettleleaf porterweed and seven closely related potential alternatives planted in northern Florida (Quincy, USDA Plant Hardiness Zone 8b) and southern Florida (Fort Pierce, USDA Plant Hardiness Zone 9b). Specific objectives include: 1) assessment of plant performance, growth, and flowering among cultivars; 2) determination of seed production, viability, and germination among cultivars; and 3) confirmation of ploidy number and potential for hybridization between the native and invasive species.

\section{Materials and Methods}

Plant material and field conditions. Eight porterweed species or cultivars were selected for this study based on local availability (Table 1). Seed- propagated jamaican porterweed and clonally propagated coral porterweed, 'Violacea' porterweed, 'Red Compact' porterweed, and nettleleaf porterweed were obtained as liners from Liner Farm Inc. (St Cloud, FL) and finished in 3.8-L containers at the Indian River Research and Education Center (Fort Pierce, FL). In addition, clonally propagated 3.8-L 'Mario Pollsa' porterweed, 'Naples Lilac' porterweed, and 'J.P.'s Pink' porterweed were obtained from Boynton Botanicals (Boynton Beach, FL). Nine uniform 3.8-L plants of each selection were installed under full sun conditions in southern Florida (Fort Pierce) and northern Florida (Quincy) on 29 Apr. 2008. Plants were placed $1.5 \mathrm{~m}$ on center in beds covered with black landscape fabric. Plants were subirrigated by filling canals (southern Florida) or dripirrigated (northern Florida) as needed (generally three times per week in spring and fall and one time per week in summer). Plants were fertilized 6 weeks after planting with $57 \mathrm{~g}$ of 12 -month $15 \mathrm{~N}-3.9 \mathrm{P}-10 \mathrm{~K}$ Osmocote Plus (Scotts Co., Marysville, $\mathrm{OH}$ ) in the area 15 to $30 \mathrm{~cm}$ from the crown. Daily rainfall, temperature, and solar radiation were recorded by Florida Automated Weather Network monitoring stations located at each site. Field conditions for southern Florida were as follows: Ankona sand with $0.8 \%$ organic matter, $\mathrm{pH} 6.8$, average monthly rainfall $18.8 \mathrm{~cm}$, mean minimum and maximum temperatures 14.2 and $33.4{ }^{\circ} \mathrm{C}$, respectively, and $80.9 \%$ relative humidity. Field conditions for northern Florida were as follows: Carnegie loamy fine sand with $2.6 \%$ organic matter, $\mathrm{pH} 4.7$, average monthly rainfall 14.6 $\mathrm{cm}$, mean minimum and maximum temperatures 9.3 and $33.7{ }^{\circ} \mathrm{C}$, respectively, and $77.0 \%$ relative humidity.

Visual quality, flowering, and plant growth. Visual quality (plant color and form) was assessed monthly for each cultivar independently at each location. Assessments of foliage color and form were performed on a scale from 1 to 5 in which $1=$ very poor quality, not acceptable, severe leaf necrosis or chlorosis, poor form; 2 = poor quality, not acceptable, large areas of necrosis or chlorosis, poor form; 3 = fair quality, marginally acceptable, somewhat desirable form and color; 4 = good quality, very acceptable and desirable color and form; and $5=$ excellent quality, perfect condition, premium color and form, peak landscape performance.

Observations of flower initiation, flowering period, and seed set were recorded monthly. Flowering was assessed on a scale from 1 to 5 in which $1=$ no flowers or flower spikes; 2 = flower spikes visible, but no open

Table 1. Nomenclature and plant description of eight porterweed cultivars. ${ }^{2}$

\begin{tabular}{lc}
\hline Common name & Species/cultivar \\
\hline Nettleleaf porterweed & $\begin{array}{c}\text { Stachytarpheta } \text { cayennensis }^{y} \\
\text { (synonym: } \text {. urticifolia) }\end{array}$
\end{tabular}

(synonym: S. urticifolia)

Jamaican porterweed Stachytarpheta jamaicensis

'Mario Pollsa' porterweed Stachytarpheta 'Mario Pollsa'

Coral porterweed

Stachytarpheta mutabilis

'Violacea' porterweed

'Naples Lilac' porterweed

Stachytarpheta mutabilis

'Violacea' (S. frantzii)

Stachytarpheta 'Naples Lilac'

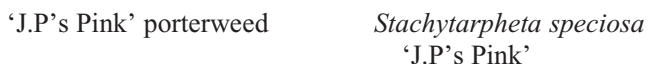

'Red Compact' porterweed Stachytarpheta speciosa 'Red Compact'
Foliage and inflorescence description

Upright, medium-sized plant reaching 1.0 to $1.5 \mathrm{~m}$, distinct and prominent leaf veins, glossy green foliage, small dark blue-purple flowers borne on thin spike open in clusters of 3 to 5 . Reportedly more cold-hardy than other porterweeds (K. Kastenholz, personal communication). Plant hardiness zone $9 \mathrm{~b}-10 \mathrm{~b}$. Polyploid.

Native to Florida. 0.5 to $1.0 \mathrm{~m}$ high, mounding, low-growing plant of horizontal habit. Small blue-purple flowers are produced either singly or 3 to 5 in a cluster on a thickened spike to 12 inch long or more. Plant hardiness zone 9a-11. Polyploid.

Larger selection growing to $2 \mathrm{~m}$, lavender flowers in clusters of 3 to 5 are produced on long erect spikes; pubescent leaves and spikes; collected in South America by Mario Pollsa and brought into the United States by Ron Boender (Butterfly World, Coconut Creek, FL) (K. Kastenholz, personal communication). Polyploid.

To $2 \mathrm{~m}$, fast-growing, large coral flowers open in clusters of 8 to 10 in succession along large arching spike. Flowers appear almost pink when temperatures are very high; leaves and sepals highly pubescent. Polyploid.

To $2 \mathrm{~m}$, fast-growing, large dark violet blooms open in clusters of 10 to 15 in succession along large arching spike; leaves and spikes highly pubescent. Polyploid.

To $2 \mathrm{~m}$ or more, purple flowers in clusters of 3 to 5 are produced on long, erect pubescent spikes. Cross between nettleleaf porterweed and 'Violacea' porterweed, created by Thomas Hucker (Former Director of Naples Botanical Garden, FL) (Kastenholz, personal communication). Polyploid.

Compact form reaching only 0.5 to $1.0 \mathrm{~m}$, true pastel pink flowers with white centers open in clusters of 5 to 8 along thin spike; more cold-sensitive than other cultivars. Found as a sport of 'Red Compact' porterweed at J.P.'s Nursery, West Palm Beach, FL (K. Kastenholz, personal communication). Diploid.

Compact form reaching only 0.5 to $1.0 \mathrm{~m}$, lighter green foliage, bright red flowers open in clusters of 4 to 6 along thin spike. Diploid.

"Plant hardiness zone is based on the U.S. Department of Agriculture zone map (USDA, 2003) and observations in Florida. Foliage and inflorescence descriptions are based on personal observations in northern and southern Florida. Ploidy level was determined by flow cytometry (see "Materials and Methods").

${ }^{y}$ Nettleleaf porterweed is listed by the Florida Exotic Pest Plant Council (FLEPPC) as a Category II invasive in south Florida (FLEPPC, 2007). 
flowers; 3 = one to several spikes with open flowers; 4 = many spikes with open flowers, average to good flowering; and $5=$ abundant flowering, peak bloom. Each month, completely senesced brown spikes (containing mature seed) were removed from each plant and counted. To calculate total seed production per plant, seeds were manually removed and counted from 10 representative spikes from each cultivar. Total spike number was multiplied with this value to estimate total seed production per plant during the 28week growing season at each location. At the termination of the study (Week 28, 10 Nov. 2008), growth indices were calculated for each plant as an average of the measured height (measured from crown to natural break in foliage) and two perpendicular widths [(height + width $1+$ width2)/3]. Although monthly field data were no longer collected after 28 weeks (termination of the experiment), plants were allowed to overwinter at each location merely to assess cold hardiness. After winter and the last frost-free day (at 46 weeks), plants were heavily pruned and regrowth was documented after 6 weeks to verify cold hardiness among cultivars and sites.

Seed germination and viability. Mature inflorescences were removed from each plant at each site and cleaned by hand using a dehulling trough (Hoffman Manufacturing, Inc., Albany, OR). Immature seeds or seeds with visible indication of pathogen or insect damage were discarded. Cleaned seeds were gravity air-dried at $22{ }^{\circ} \mathrm{C}$ for 48 to $72 \mathrm{~h}$ before analysis. In accordance with the Tetrazolium Testing Handbook, Contribution No. 29 Association of Official Seed Analysts rules (Peters, 2000), pregermination viability tests were replicated twice on a subset of 100 seeds per cultivar from both sites. Seeds were pretreated by allowing them to imbibe between moist blotter paper overnight at room temperature. Seeds were then cut longitudinally and stained for 18 to $24 \mathrm{~h}$ at 30 to $35^{\circ} \mathrm{C}$ in $1.0 \%$ tetrazolium $(2,3,5$-triphenyl chloride) solution with positive staining patterns confirming seed viability (Mid-West Seed Service Inc., Brookings, SD). An additional 400 seeds per cultivar from both sites were subjected to germination tests (four replications of 100 seeds per test) at $30 / 20{ }^{\circ} \mathrm{C}(8-\mathrm{h}$ photoperiod at $30{ }^{\circ} \mathrm{C}$ followed by $16 \mathrm{~h}$ darkness at $20{ }^{\circ} \mathrm{C}$ ) for $28 \mathrm{~d}$ (Mid-West Seed Service Inc.). Seeds were arranged in germination boxes (containing two layers of moistened blue blotter paper) that were placed in incubators equipped with cool-white fluorescent lamps. Germination readings were taken at Day 14 with a final count at Day 28. Ungerminated seed were subjected to postgermination viability tests (as described previously) and used to report percent germination of viable seeds.

Using a subsample of seed collected from cultivars grown in Fort Pierce, an additional experiment was conducted to determine temperature effects on seed germination. Cleaned seeds were treated with $0.6 \%$ sodium hypochlorite for $5 \mathrm{~min}$, rinsed three times with deionized water, and soaked over- night in aerated water. Floating seeds were discarded. Individual treatments consisted of four replications of 50 seeds per cultivar in $10.9 \times 10.9-\mathrm{cm}$ transparent polystyrene germination boxes (Hoffman Manufacturing, Inc., Albany, OR) containing two sheets of germination paper (Hoffman Manufacturing Inc.) moistened with $15 \mathrm{~mL}$ deionized water. Germination boxes were placed in temperature- and light-controlled chambers equipped with cool-white fluorescent lamps (Model 818; Precision Scientific, Winchester, VA). Germination boxes were placed in 20/10, 25/ $15,30 / 20$, and $35 / 25{ }^{\circ} \mathrm{C}$. The photoperiod was administered by providing $12 \mathrm{~h}$ light at $20,25,30$ or $35^{\circ} \mathrm{C}$ (photosynthetic photon flux was 22 to $30 \mu \mathrm{mol} \cdot \mathrm{m}^{-2} \cdot \mathrm{s}^{-1}$ at shelf level) followed by $12 \mathrm{~h}$ dark at $10,15,20$, or $25^{\circ} \mathrm{C}$, respectively. Germination of seed was monitored daily for a period of $28 \mathrm{~d}$. An additional 5 to $10 \mathrm{~mL}$ of deionized water was added to germination boxes as needed. A seed was considered germinated when radicle emergence was $2.0 \mathrm{~mm}$ or greater. At the end of the germination period, final germination percentage (FGP) and T50 (days to $50 \%$ of FGP) were determined per germination box.

Ploidy analysis and hybridization potential. Ploidy level of the porterweed cultivars was analyzed by flow cytometry (Viloria and Grosser, 2005). Several young, recently matured leaves were collected from containerized stock plants and a small piece of leaf tissue $\left(\approx 0.5 \mathrm{~cm}^{2}\right)$ was chopped thoroughly using a sharp razor blade in Cystain ultraviolet Precise $\mathrm{P}$ extraction buffer (Partec $\mathrm{GmbH}$, Münster, Germany). The homogenate was incubated for $1 \mathrm{~min}$ and then filtered through a Partec 30- $\mu \mathrm{m}$ Cell-Tric disposable filter (Partec $\mathrm{GmbH}$ ). Staining buffer (HR-B; Partec $\mathrm{GmbH}$ ) was added to the suspension of nuclei and the samples were analyzed on a ploidy analyzer (PA-1; Partec $\mathrm{GmbH}$ ) following the manufacturer's recommendations.

To assess the hybridization potential between the invasive nettleleaf and the native jamaican porterweed, manual crosses were performed between nettleleaf porterweed $x$ jamaican porterweed and the reciprocal. One 3.8-L plant for each porterweed was grown in a greenhouse. For each plant, three flower spikes were selected and tagged. As flower buds matured sequentially along the spike, they were emasculated before anther dehiscence. The corolla and attached anthers were removed by pulling them gently, and the exposed stigma was pollinated. For identification, each pollinated flower was marked by coloring the remaining sepal on the spike with a permanent marker. This process was repeated during a period of $10 \mathrm{~d}$, completing $\approx 20$ pollinations per spike to a total of 55 pollinations for nettleleaf porterweed $\times$ jamaican porterweed and 62 pollinations for the reciprocal cross.

Four weeks after pollinations were completed, tips of the pollinated flower spikes were cut to prevent further flowering and promote ripening. Spikes were harvested when they were brown and brittle and could be detached easily from the plant. This began $\approx 80 \mathrm{~d}$ after pollination for nettleleaf porterweed and $110 \mathrm{~d}$ for jamaican porterweed. Putative hybrid seeds were cleaned and germinated at $25 / 15{ }^{\circ} \mathrm{C}$ for 2 weeks before transfer to the greenhouse for phenotype evaluation.

Experimental design and statistical analysis. The field experiments were conducted similarly in northern and southern Florida. A randomized complete block experimental design was used with eight cultivars placed in three-plant plots replicated three times (blocks). Visual quality and flowering data were collected monthly for each plant. At 28 weeks, growth data were collected on each plant sample, subjected to analysis of variance (ANOVA), and significant means separated by least significant difference (LSD) at $P=0.05$. For the first germination study, data were subjected to ANOVA and significant cultivar means separated by LSD at $P=0.05$. For the second germination study, a split block experimental design was used with temperature as the main block and cultivar as the split plot. Percentage data were transformed by a sqrt arcsine before conducting an ANOVA within temperatures. Transformed means were separated by a Duncan's multiple range test $(P$ $=0.05)$. Untransformed cultivar means are presented in tables.

\section{Results and Discussion}

Visual quality and plant growth. Visual quality of porterweed varied by location and cultivar (Fig. 1A; Table 2). In both locations, peak visual quality values (very good to excellent) were recorded from April to June and August to October for most of the cultivars with the exception of coral porterweed that gradually declined in northern Florida and 'J.P.'s Pink' porterweed that sharply declined and eventually died in northern and southern Florida. Warm and wet conditions in July [resulting in temporary leaf rust (Puccinia spp.)] and cold temperatures in November contributed to lower visual quality readings during these months in both locations. Overall, nettleleaf porterweed, jamaican porterweed, 'Naples Lilac' porterweed, and 'Red Compact' porterweed had similarly high visual quality ratings in northern Florida (Table 2). In southern Florida, 'Violacea' porterweed, nettleleaf porterweed, and 'Red Compact' porterweed had the highest overall visual quality ratings (Table 2). In northern Florida, coral porterweed and 'J.P.'s Pink' porterweed had the lowest overall visual quality ratings. In southern Florida, 'Mario Pollsa' and 'J.P.'s Pink' porterweed had the lowest overall visual quality ratings.

Of the porterweed cultivars evaluated in northern and southern Florida, after 28 weeks, 'Mario Pollsa' porterweed was the tallest $(106 \mathrm{~cm})$ followed by 'Naples Lilac' porterweed $(103 \mathrm{~cm})$ (data not presented). 'Naples Lilac' porterweed had the greatest growth index at both sites, because plants were significantly wider than the other 
cultivars (Table 2). It is of interest to note that on average, porterweed cultivars were 1.2 to 1.8 times larger in northern Florida than in southern Florida after 28 weeks. After completion of the study, frost killed aboveground portions of all plants during the winter in northern and southern Florida. In northern Florida, spring regrowth was not observed for any of the plants regardless of cultivar. In southern Florida, winter survival (and subsequent regrowth) was $100 \%$ for jamaican porterweed, 'Violacea' porterweed, 'Naples Lilac' porterweed, and nettleleaf porterweed. Less winter survival was observed for 'Mario Pollsa' porterweed (78\%), coral porterweed (67\%), 'Compact Red' porterweed $(56 \%)$, and 'JP's Pink' porterweed $(0 \%)$. This indicates that regardless of species, porterweed performs as an annual in northern Florida. In southern Florida, porterweed can generally be used as a perennial, but dwarf cultivars may be less hardy or vigorous.

Flowering. Porterweed flowers continually and indeterminately. Although flower performance varied by cultivar and location, there were at least some flowers (and usually many) on each plant throughout the duration of the study (Fig. 1B; Table 2). Regardless of cultivar or site, peak flowering times generally were in late spring to early summer (May to June) and again in the early fall (September to October) (Fig. 1B). Within 28 weeks, plants in northern Florida produced an average of 3.4 times more flower spikes than plants in southern Florida. Average number of spent flower spikes from a single plant ranged from 49 (coral porterweed) to 651 (nettleleaf porterweed) in northern Florida or 26 (coral porterweed) to 203 (nettleleaf porterweed) in southern Florida. Overall, 'Naples Lilac' porterweed and 'Red Compact' porterweed had similarly high flower ratings (4.25 and 4.07, respectively) in northern Florida (Table 2). In southern Florida, nettleleaf porterweed, 'Naples Lilac' porterweed, and 'Red Compact' porterweed had the highest overall flower ratings $(3.97,3.88$, and 3.81, respectively) (Table 2). At both locations, coral porterweed and 'J.P.'s Pink' porterweed had the lowest flower ratings. This information can be useful from a nursery and landscape perspective as well as from an invasive perspective because length of the flowering period has been found to be greater in weedy species as compared with nonweedy species (Perrins et al., 1992). Long flowering periods may allow greater accessibility to pollinators and a greater chance of seed set (Reichard and Hamilton, 1997).

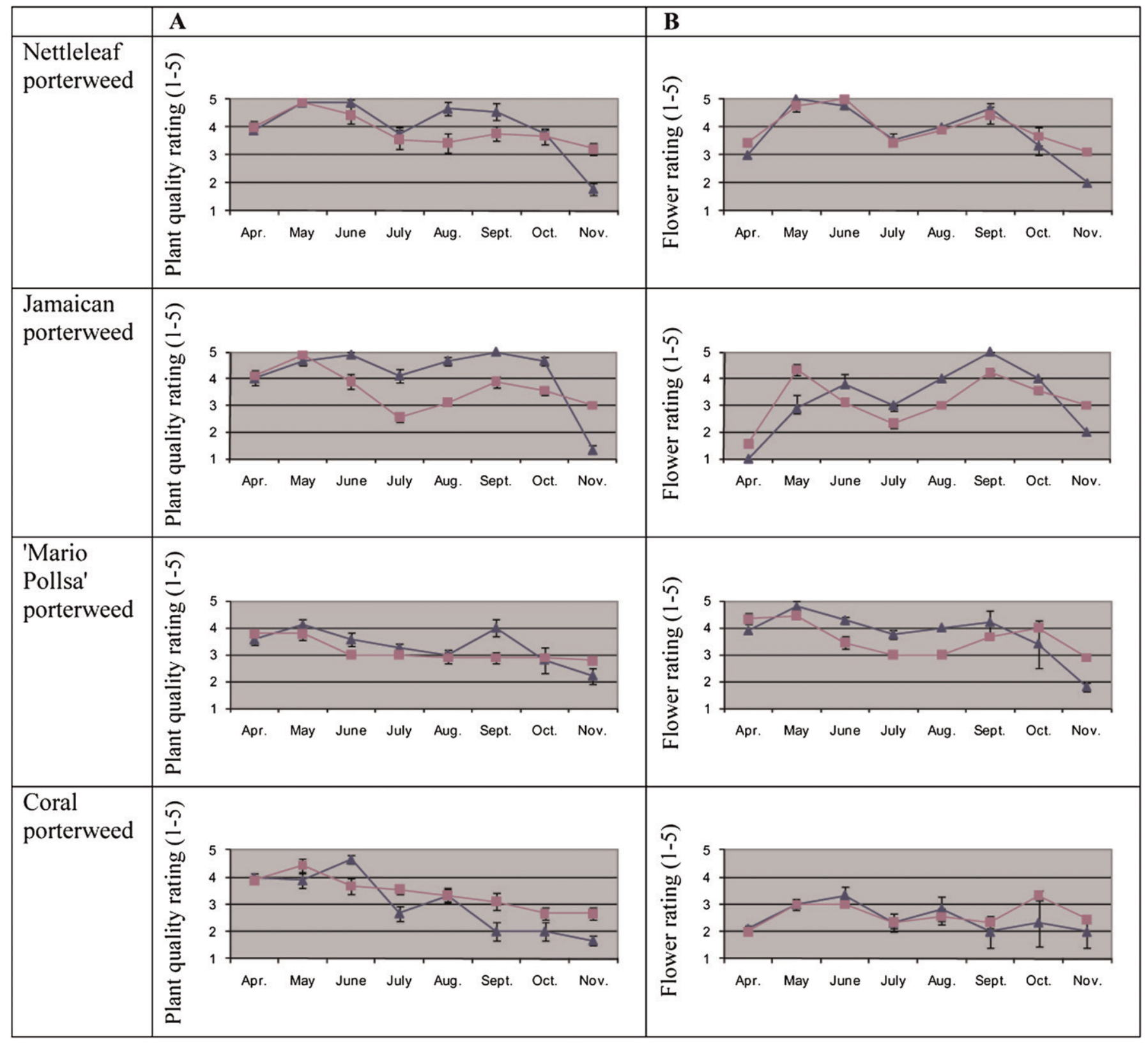

Fig. 1. (Continued on next page) 


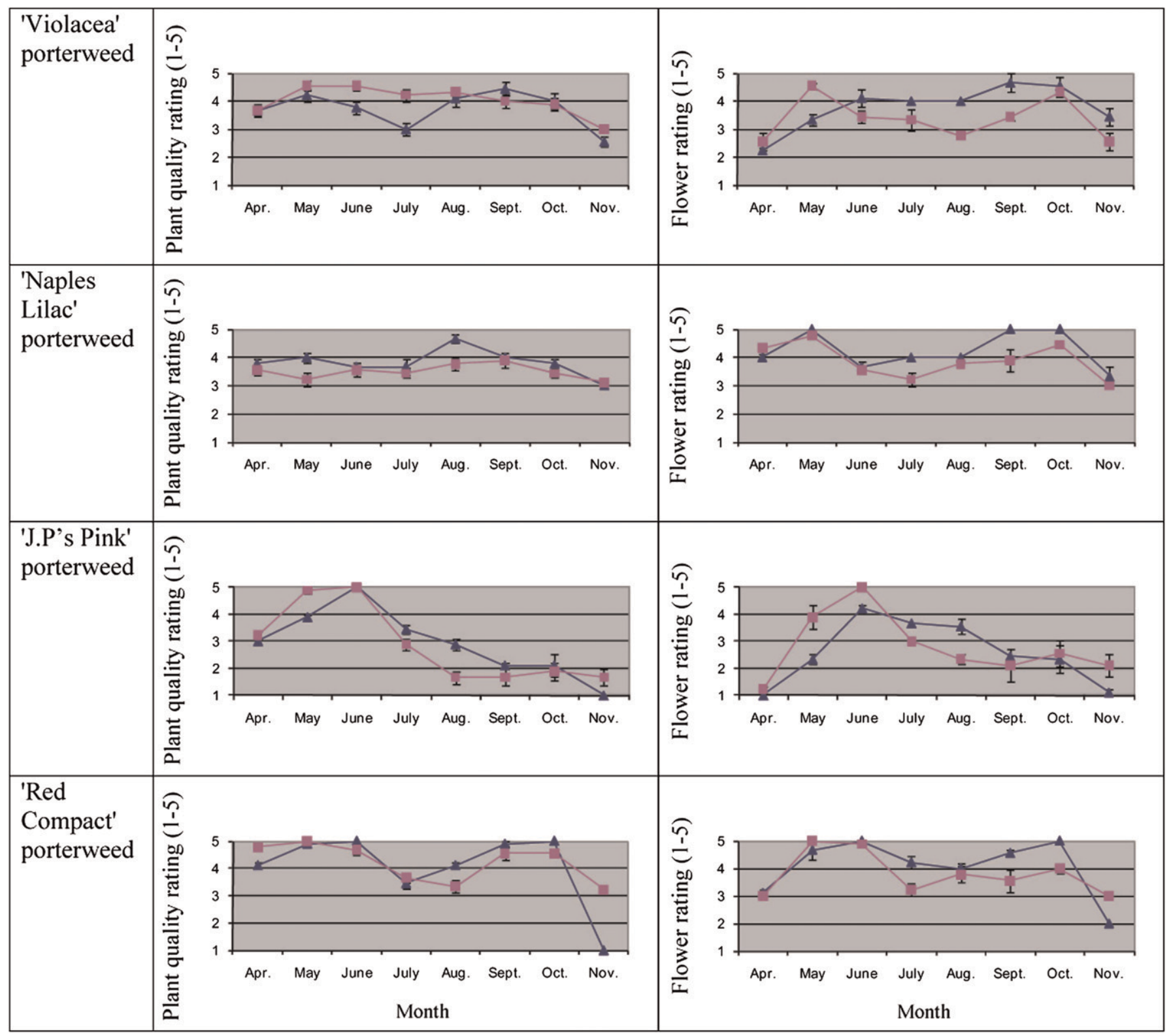

Fig. 1. Monthly visual quality (color and form) and flowering of eight porterweed cultivars grown for 28 weeks in northern ( $\mathbf{\Delta})$ and southern ( $\mathbf{\square})$ Florida. Visual quality (A) was rated 1 (very poor) to 5 (excellent). Flowering $(\mathbf{B})$ was rated 1 (no flower spikes) to 5 (abundant flower spikes). Mean values $\pm \mathrm{SE}$ are shown ( $\mathrm{n}=3$ ).

Table 2. Growth index, average monthly flower rating (scale 1-5), and average monthly visual quality rating (scale 1-5) of eight porterweed cultivars grown for 28 weeks in northern and southern Florida.

\begin{tabular}{|c|c|c|c|c|c|c|}
\hline \multirow[b]{2}{*}{ Species/cultivar } & \multicolumn{2}{|c|}{ Growth index } & \multicolumn{2}{|c|}{ Avg flower rating ${ }^{z}$} & \multicolumn{2}{|c|}{ Avg visual quality rating ${ }^{y}$} \\
\hline & Northern Florida & Southern Florida & Northern Florida & Southern Florida & Northern Florida & Southern Florida \\
\hline Jamaican porterweed & 123.04 & 67.30 & 3.21 & 3.14 & 4.17 & 3.63 \\
\hline Coral porterweed & 101.33 & 96.74 & 2.49 & 2.62 & 3.03 & 3.42 \\
\hline 'Violacea' porterweed & 137.48 & 92.07 & 3.80 & 3.38 & 3.72 & 4.03 \\
\hline 'Naples Lilac' porterweed & 184.15 & 118.44 & 4.25 & 3.88 & 3.82 & 3.50 \\
\hline 'J.P.'s Pink' porterweed & 53.30 & 46.15 & 2.58 & 2.78 & 2.93 & 2.86 \\
\hline
\end{tabular}

${ }^{\mathrm{z}}$ Based on a flowering scale of 1 to 5 in which $1=$ no flowers and $5=$ abundant flowering or peak bloom.

${ }^{\mathrm{y} B a s e d}$ on a visual quality scale (foliage and form) of 1 to 5 in which $1=$ very poor quality and $5=$ excellent quality.

${ }^{\mathrm{x}}$ Least significant difference (LSD) at $P=0.05$ level.

Seed production, viability, and germination. Within 8 to 12 weeks, each of the eight cultivars evaluated produced fruit characterized as an oblong-linear schizocarp splitting at maturity into two mericarps (Munir, 1992). However, there were significant differences in the actual embryo development (and hence viability) among cultivars. In northern Flor- ida, jamaican porterweed had the greatest seed viability (78\%) followed by 'J.P.'s Pink' porterweed $(43 \%)$, 'Red Compact' porterweed $(41 \%)$, and nettleleaf porterweed 
(39\%) (Table 3). In southern Florida, jamaican porterweed and nettleleaf porterweed also had the greatest seed viability (93\% and $80 \%$, respectively) compared with the other cultivars. The greater seed viability of nettleleaf porterweed (FLEPPC Category II invasive) in southern Florida compared with northern Florida is of interest. A suite of factors has been found to influence variation in seed dormancy, including population, year, mother plant condition (Andersson and Milberg, 1998), and temperature and soil moisture during seed maturation (Peters, 1982). Yet, location did not appear to influence seed viability of the other seven cultivars in this study. At both locations, seed viability was less than $10 \%$ for 'Mario Pollsa' porterweed ( $7 \%$ to $10 \%)$, coral porterweed ( $7 \%$ to $8 \%$ ), 'Violaceae' porterweed $(0 \%)$, and 'Naples Lilac' porterweed ( $1 \%$ to $2 \%)$ (Table 3).

Pregermination viability data generally correlated with percent germination within $28 \mathrm{~d}$, indicating that seeds from most cultivars do not possess a physical or physiological dormancy as defined by Baskin and Baskin (2001) and that seeds are not decaying during the germination period. However, at both locations, seeds produced from the dwarf cultivars ('J.P.'s Pink' porterweed and 'Red Compact' porterweed) were $42 \%$ to $52 \%$ dormant (Table 3 ). Dormancy was not alleviated when seeds of these cultivars were germinated at a wide range of temperatures $\left(20 / 10,25 / 15,30 / 20\right.$, and $35 / 25{ }^{\circ} \mathrm{C}$ ) (Table $4)$. It is likely that these cultivars require additional stratification or scarification treatments before germination.

More than $75 \%$ of nettleleaf porterweed seed (collected in southern Florida) germinated at $20 / 10,25 / 15,30 / 20$, and $35 / 25{ }^{\circ} \mathrm{C}$ (Table 4). Several weed species have been

Table 3. Percent viability and germination of seed collected from eight porterweed cultivars grown in northern and southern Florida. ${ }^{2}$

\begin{tabular}{|c|c|c|c|c|c|}
\hline \multicolumn{6}{|c|}{ Northern Florida ${ }^{y}$} \\
\hline Species/cultivar & $\begin{array}{l}\text { Pregermination } \\
\text { viability }(\%)\end{array}$ & $\begin{array}{c}\text { Germination }^{\mathrm{w}} \\
(\%)\end{array}$ & $\begin{array}{c}\text { Dormant } \\
(\%)\end{array}$ & $\begin{array}{c}\text { Total viable } \\
(\%)\end{array}$ & $\begin{array}{l}\text { Germination of } \\
\text { viable seed }(\%)\end{array}$ \\
\hline Nettleleaf porterweed & $38.5 \mathrm{~b}$ & $32.8 \mathrm{~b}$ & $6.3 \mathrm{c}$ & $39.0 \mathrm{~d}$ & $84.0 \mathrm{a}$ \\
\hline Jamaican porterweed & $77.5 \mathrm{a}$ & $60.3 \mathrm{a}$ & $17.8 \mathrm{~b}$ & $78.0 \mathrm{a}$ & $77.2 \mathrm{ab}$ \\
\hline 'Mario Pollsa' porterweed & $9.5 \mathrm{c}$ & $3.5 \mathrm{c}$ & $6.5 \mathrm{c}$ & $10.0 \mathrm{e}$ & $35.0 \mathrm{bc}$ \\
\hline Coral porterweed & $6.5 \mathrm{c}$ & $1.5 \mathrm{~cd}$ & $5.5 \mathrm{c}$ & $7.0 \mathrm{f}$ & $21.4 \mathrm{~cd}$ \\
\hline 'Violacea' porterweed & $0.0 \mathrm{~d}$ & $0.0 \mathrm{e}$ & $0.0 \mathrm{~d}$ & $0.0 \mathrm{~h}$ & $0.0 \mathrm{~d}$ \\
\hline 'Naples Lilac' porterweed & $0.5 \mathrm{~d}$ & $1.3 \mathrm{cde}$ & $0.3 \mathrm{~d}$ & $1.5 \mathrm{~g}$ & $75.0 \mathrm{a}$ \\
\hline 'J.P's Pink' porterweed & $42.5 \mathrm{~b}$ & $0.8 \mathrm{de}$ & $42.3 \mathrm{a}$ & $43.0 \mathrm{~b}$ & $1.8 \mathrm{~d}$ \\
\hline 'Red Compact' porterweed & $40.5 \mathrm{~b}$ & $0.3 \mathrm{de}$ & $40.8 \mathrm{a}$ & $41.0 \mathrm{c}$ & $0.6 \mathrm{~d}$ \\
\hline \multicolumn{6}{|c|}{ Southern Florida ${ }^{y}$} \\
\hline Species/cultivar & $\begin{array}{l}\text { Pre-germination } \\
\text { viability }^{\mathrm{x}}(\%)\end{array}$ & $\begin{array}{c}\text { Germination }^{\mathrm{w}} \\
(\%)\end{array}$ & $\begin{array}{c}\text { Dormant } \\
(\%)\end{array}$ & $\begin{array}{c}\text { Total viable } \\
(\%)\end{array}$ & $\begin{array}{l}\text { Germination of } \\
\text { viable seed }(\%)\end{array}$ \\
\hline Nettleleaf porterweed & $79.5 \mathrm{a}$ & $69.3 \mathrm{~b}$ & $1.0 \mathrm{de}$ & $70.3 \mathrm{~b}$ & $98.8 \mathrm{a}$ \\
\hline Jamaican porterweed & $92.5 \mathrm{a}$ & $84.5 \mathrm{a}$ & $8.5 \mathrm{c}$ & $93.0 \mathrm{a}$ & $90.9 \mathrm{~b}$ \\
\hline 'Mario Pollsa' porterweed & $6.5 \mathrm{c}$ & $11.0 \mathrm{c}$ & $0.0 \mathrm{e}$ & $11.0 \mathrm{e}$ & $100.0 \mathrm{a}$ \\
\hline Coral porterweed & $8.0 \mathrm{c}$ & $0.8 \mathrm{e}$ & $7.3 \mathrm{c}$ & $8.0 \mathrm{e}$ & $9.4 \mathrm{de}$ \\
\hline 'Violacea' porterweed & $0.0 \mathrm{~d}$ & $0.0 \mathrm{e}$ & $0.0 \mathrm{e}$ & $0.0 \mathrm{~g}$ & $0.0 \mathrm{e}$ \\
\hline 'Naples Lilac' porterweed & $1.5 \mathrm{~cd}$ & $0.8 \mathrm{e}$ & $1.3 \mathrm{~d}$ & $2.0 \mathrm{f}$ & $37.5 \mathrm{c}$ \\
\hline 'J.P's Pink' porterweed & $46.0 \mathrm{~b}$ & $4.5 \mathrm{~d}$ & $41.5 \mathrm{~b}$ & $46.0 \mathrm{~d}$ & $9.8 \mathrm{~d}$ \\
\hline 'Red Compact' porterweed & $56.5 \mathrm{~b}$ & $4.8 \mathrm{~d}$ & $52.3 \mathrm{a}$ & $57.0 \mathrm{c}$ & $8.3 \mathrm{~d}$ \\
\hline
\end{tabular}

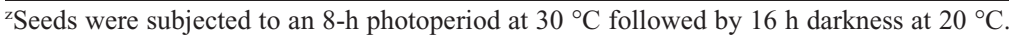

${ }^{y}$ Mean separation was conducted by Duncan's multiple range test on transformed means. Different lowercase letters within columns are significantly different $(P=0.05)$.

${ }^{x}$ Performed on a subset of 200 seed (two replications of 100).

${ }^{\text {w}}$ Performed on 400 seed (four replications of 100). Remaining seeds that did not germinate were subjected to viability tests and used to calculate viable seed germination percentages.

Table 4. Final germination percent and number of days to $50 \%$ of final germination (T50) of seed collected from eight porterweed cultivars grown in southern Florida. ${ }^{z}$

\begin{tabular}{|c|c|c|c|c|c|c|c|c|}
\hline \multirow[b]{2}{*}{ Species/cultivar } & \multicolumn{4}{|c|}{ Germination $(\%)^{y}$} & \multicolumn{4}{|c|}{ T50 (days) } \\
\hline & $20 / 10$ & $25 / 15$ & $30 / 20$ & $35 / 25$ & $20 / 10$ & $25 / 15$ & $30 / 20$ & $35 / 25$ \\
\hline Nettleleaf porterweed & $75.5 \mathrm{a}$ & $79.5 \mathrm{a}$ & $80.5 \mathrm{a}$ & $88.0 \mathrm{a}$ & $21.3 \mathrm{~b}$ & $8.8 \mathrm{~cd}$ & $7.0 \mathrm{~cd}$ & $5.0 \mathrm{c}$ \\
\hline Jamaican porterweed & $43.0 \mathrm{~b}$ & $85.5 \mathrm{a}$ & $83.5 \mathrm{a}$ & $48.0 \mathrm{~b}$ & $16.5 \mathrm{c}$ & $8.0 \mathrm{~cd}$ & $7.0 \mathrm{~cd}$ & $4.0 \mathrm{c}$ \\
\hline 'Mario Pollsa' porterweed & $10.5 \mathrm{c}$ & $9.0 \mathrm{~b}$ & $11.5 \mathrm{~b}$ & $7.5 \mathrm{~cd}$ & $12.5 \mathrm{~d}$ & $5.5 \mathrm{~d}$ & $4.0 \mathrm{~d}$ & $4.0 \mathrm{c}$ \\
\hline Coral porterweed & $2.5 \mathrm{~d}$ & $9.5 \mathrm{~b}$ & $6.0 \mathrm{bc}$ & $10.5 \mathrm{c}$ & $22.3 \mathrm{~b}$ & $12.0 \mathrm{bcd}$ & $7.5 \mathrm{~cd}$ & $9.8 \mathrm{~b}$ \\
\hline 'Violacea'porterweed & $0.0 \mathrm{e}$ & $0.0 \mathrm{c}$ & $0.0 \mathrm{~d}$ & $0.0 \mathrm{e}$ & $-^{x}$ & $-^{x}$ & $-^{x}$ & $\complement^{x}$ \\
\hline 'Naples Lilac' porterweed & $1.5 \mathrm{~d}$ & $1.5 \mathrm{c}$ & $1.0 \mathrm{~d}$ & $3.5 \mathrm{~d}$ & $26.0 \mathrm{a}$ & $19.0 \mathrm{a}$ & $19.5 \mathrm{a}$ & $14.7 \mathrm{a}$ \\
\hline 'J.P’s Pink' porterweed & $0.0 \mathrm{e}$ & $0.5 \mathrm{c}$ & $7.5 \mathrm{bc}$ & $9.5 \mathrm{c}$ & $-^{x}$ & $16.0 \mathrm{ab}$ & $16.8 \mathrm{ab}$ & $14.3 \mathrm{a}$ \\
\hline 'Red Compact' porterweed & $0.0 \mathrm{e}$ & $0.5 \mathrm{c}$ & $3.0 \mathrm{~cd}$ & $10.5 \mathrm{c}$ & $\mathrm{C}^{\mathrm{x}}$ & $14.0 \mathrm{abc}$ & $12.0 \mathrm{bc}$ & $14.8 \mathrm{a}$ \\
\hline
\end{tabular}

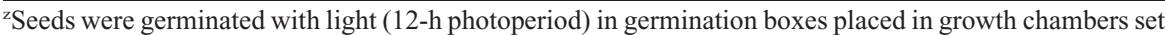
at $20 / 10,25 / 15,30 / 2,0$ and $35 / 25{ }^{\circ} \mathrm{C}$ for $28 \mathrm{~d}$.

yPerformed on 200 seed (four replications of 50). Mean separation was conducted by Duncan's multiple range test on transformed means. Different lowercase letters within columns are significantly different $(P=0.05)$

${ }^{\mathrm{x}} \mathrm{T} 50$ could not be calculated as a result of zero percent germination. shown to germinate over a wide range of temperatures (Balyan and Bhan, 1986; Susko et al., 1999); and the consensus of comparative studies is that alien invaders germinate earlier, better, or at a wider range of conditions (Pyšek and Richardson, 2007). The jamaican porterweed also had high germination at $25 / 15$ and $30 / 20{ }^{\circ} \mathrm{C}$, but germination was dramatically reduced by $50 \%$ and $43 \%$ at the lowest $\left(20 / 10^{\circ} \mathrm{C}\right)$ and highest $\left(35 / 25^{\circ} \mathrm{C}\right)$ temperature treatments, respectively. Although not an objective of this study, it is of interest to note that germination of jamaican porterweed seed was considerably less if germination experiments are performed in darkness. At $25 / 15$ and $30 / 20{ }^{\circ} \mathrm{C}$, germination in the dark was $61 \%$ and $91 \%$ less, respectively, than seeds that received $12 \mathrm{~h}$ of light (data not presented). However in contrast, nettleleaf porterweed had similarly high germination with light ( $80 \%$ to $81 \%$ ) or without light ( $78 \%$ to $83 \%$ ) at $25 / 15$ and $30 /$ $20{ }^{\circ} \mathrm{C}$ (data not presented). Seeds that do not require light for germination in petri dishes may be more capable of germinating in nature when shaded by leaf litter or a tree canopy or after burial in the soil (Baskin and Baskin, 2001).

With the exception of jamaican porterweed and nettleleaf porterweed, all other cultivars had $11.5 \%$ or less germination. The least number of mean days to achieve $50 \%$ of total germination varied with temperature and cultivar (Table 4 ). At $20 / 10{ }^{\circ} \mathrm{C}$, T50 values ranged from 13 d ('Mario Pollsa' porterweed) to $26 \mathrm{~d}$ ('Naples Lilac' porterweed), whereas at $35 / 25^{\circ} \mathrm{C}$, T50 values were lower ranging from 4 or $5 \mathrm{~d}$ (nettleleaf porterweed, jamaican porterweed, and 'Mario Pollsa' porterweed) to 14 or $15 \mathrm{~d}$ ('Naples Lilac', 'J.P.'s Pink', and 'Red Compact' porterweed). Germination rate can be a useful measure of the speed or velocity of germination because germination patterns can be different even if final germination percentages are almost identical (Hartmann et al., 2002). In addition, invasiveness has been positively correlated with the rate of germination (Forcella et al., 1986).

Average number of seeds per inflorescence spike varied widely among cultivars with 'Red Compact' porterweed having the largest number of seeds per spike and 'Mario Pollsa' porterweed having the least number of seeds per spike (Table 5). The flowers of porterweed are semi-immersed in depressions or furrows in the rachis of the spike making it possible to estimate total seed production, even after dehiscence. In other studies, stem count has been used to predict the number of inflorescences and the inflorescence length has been used to predict the number of seed capsules (Ebeling et al., 2007). Also, seed capsule weight has been used to project number of seeds per plant (Wilson et al., 2004b). In the present study, percent germination was included in the equation to estimate potential seedling progeny. If calculating the average number of seeds per plant with projected germination $(60 \%$ to $85 \%)$ under optimal conditions, 
Table 5. Average number of seeds per flower spike, average number of spikes per plant, and average number of potential seedlings per plant of eight porterweed cultivars grown for 28 weeks in northern and southern Florida.

\begin{tabular}{|c|c|c|c|c|c|}
\hline \multirow[b]{2}{*}{ Species/cultivar } & \multirow{2}{*}{$\begin{array}{l}\text { Avg no. of } \\
\text { seeds per } \\
\text { spike } \\
(\mathrm{n}=10)\end{array}$} & \multicolumn{2}{|c|}{$\begin{array}{l}\text { Avg number of } \\
\text { spikes per plant }\end{array}$} & \multicolumn{2}{|c|}{$\begin{array}{l}\text { Potential seedlings } \\
\text { per plant } \mathrm{y}^{\mathrm{y}}\end{array}$} \\
\hline & & $\begin{array}{l}\text { Northern } \\
\text { Florida }\end{array}$ & $\begin{array}{c}\text { Southern } \\
\text { Florida }\end{array}$ & $\begin{array}{l}\text { Northern } \\
\text { Florida }\end{array}$ & $\begin{array}{c}\text { Southern } \\
\text { Florida }\end{array}$ \\
\hline Nettleleaf porterweed & 189 & 651 & 203 & 40,300 & 26,600 \\
\hline Jamaican porterweed & 399 & 531 & 131 & 127,400 & 44,200 \\
\hline 'Mario Pollsa' porterweed & 101 & 283 & 97 & 1,000 & 1,100 \\
\hline Coral porterweed & 179 & 49 & 26 & 100 & 40 \\
\hline 'Violacea' porterweed & 297 & 226 & 53 & 0 & 0 \\
\hline 'Naples Lilac' porterweed & 147 & 467 & 99 & 900 & 100 \\
\hline 'J.P's Pink' porterweed & 248 & 140 & 66 & 300 & 700 \\
\hline 'Red Compact' porterweed & 427 & 413 & 115 & 400 & 2,300 \\
\hline
\end{tabular}

${ }^{\mathrm{z}}$ Value represents spent flower spikes produced during the 28 -week trial.

${ }^{\mathrm{y}}$ Calculated using germination percentages from respective sites.

jamaican porterweed has the potential to produce over 127 thousand seedlings in northern Florida and over 44 thousand seedlings in southern Florida (Table 5). Nettleleaf porterweed (with $33 \%$ to $70 \%$ germination) has the potential to produce over 40 thousand seedlings in northern Florida and 26 thousand seedlings in southern Florida. This information is useful, because length of flowering period does not necessarily indicate high seed production, and high seed production does not necessarily indicate high germination. For example, 'Dartmoor' butterfly bush (Buddleja davidii $\times$ Buddleja davidii var. nanhoensis) continually flowered $(50 \%$ to $75 \%$ canopy coverage) throughout much of a study in west and south Florida (Wilson et al., 2004a) yet produced relatively few seeds compared with the other butterfly bush cultivars (Wilson et al., 2004b). Likewise, in another study, 'Little Kitten' japanese silver grass (Miscanthus sinensis) had the highest number of inflorescence panicles in southern Florida but less than half of the seeds were viable, and of these, only $54 \%$ germinated (Wilson and Knox, 2006). As Mandák (2003) points out, percentage of seed germination is only one important factor to consider when fully characterizing the invasive potential of plants. Seed bank establishment, seed dispersal, resource allocation, physiological and morphological adaptations to specialized environments, life history traits, and propagule pressure all contribute to plant invasiveness (Baruch and Goldstein, 1999; Pemberton and Liu, 2009; Pyšek and Richardson, 2007; Reichard and Hamilton, 1997; Rejmánek, 2000).

Ploidy identification and hybridization potential. 'Red Compact' and 'J.P.'s Pink' porterweed were determined to be diploids (Table 1). The $\mathrm{C}$ value of the other porterweed cultivars was two to 2.5 times that of 'Red Compact' or 'J.P.'s Pink', indicating that these cultivars might be tetraploids or pentaploids. It is known that there is a range of polyploids and aneuploids in the porterweed genus (Fedorov, 1974; Sanders, 2001). Therefore, the ploidy level of these cultivars (except for 'Red Compact' and 'J.P.'s Pink') should be considered tentative without further confirmation from mitotic and/or meiotic chromosome counting.
Manual pollinations between nettleleaf porterweed and jamaican porterweed were successful. Fruit set in each of the three pollinated flower spikes for $S$. jamaicensis $\times$ S. urticifolia ranged from $10 \%$ to $20 \%$ with an average of $16.1 \%$, and from $12.5 \%$ to $22.2 \%$ for the reciprocal with an average of $16.4 \%$. Because each fruit contains two seeds, a total of 20 and 18 seeds were obtained for each cross. In addition, under greenhouse conditions, it was observed that both nettleleaf porterweed and jamaican porterweed plants had fruit set from self-pollination. Thirty self-pollinated seeds per plant were harvested to be used as controls to compare germination rates and morphology with the putative hybrid progenies. Future work will evaluate putative hybrid seedlings using morphological markers that distinguish both parents to confirm their hybrid origin.

The results of this study suggest 'Naples Lilac' porterweed (which was essentially seed-sterile) performed as well, if not better than, nettleleaf porterweed (a Category II invasive in Florida that produces abundant, viable seed). Other female sterile or almost sterile alternatives with good flowering and visual quality were 'Mario Pollsa' porterweed and 'Violacea' porterweed. The dwarf 'Red Compact' porterweed outperformed and lived longer than the dwarf 'J.P.'s Pink' porterweed. The native jamaican porterweed was much more prostrate and overall had less flower impact than the invasive nettleleaf porterweed but was ranked similarly in visual quality. Variation in ploidy level was found among porterweed cultivars. Although not straightforward as a result of its floral biology (autogamy, small flower size, inflorescence structure, and long fruit maturation time), manual cross-pollination between the native and invasive porterweed appears to be possible. The ecological risks associated with native gene pool contamination and the availability of highly ornamental, sterile, closely related porterweed alternatives suggest limiting the production and use of nettleleaf porterweed in Florida.

\section{Literature Cited}

Andersson, L. and P. Milberg. 1998. Variation in seed dormancy among mother plants, popula- tions and years of seed collection. Seed Sci. Res. 8:29-38.

Atkins, S. 2005. The genus Stachytarpheta (Verbenaceae) in Brazil. Kew Bull. 60:161-272.

Balyan, R.S. and V.M. Bhan. 1986. Germination of horse purslane (Trianthema portulacastrum) in relation to temperature, storage conditions, and seeding depths. Weed Sci. 34:513-515.

Baruch, Z. and G. Goldstein. 1999. Leaf construction cost, nutrient concentration, and net $\mathrm{CO} 2$ assimilation of native and invasive species in Hawaii. Oecologia 121:183-192.

Baskin, C.C. and J.M. Baskin. 2001. Seeds. Academic Press, San Diego, CA.

Burt, J.W., A.A. Munir, J. Piovia-Scott, K.E. Veblen, A.L. Chang, J.D. Grossman, and H.W. Weiskel. 2007. Preventing horticultural introductions of invasive plants: Potential efficacy of voluntary initiatives. Biol. Invasions 9:909-923.

Caldwell, D. 2005. Cute plants that take over your yard...Blue porter weed. Naples Daily News. 1 Jan. 2005.

Caley, P., R.H. Groves, and R. Barker. 2008. Estimating the invasion success of introduced plants. Divers. Distrib. 14:196-203.

Culley, T.M. and N.A. Hardiman. 2009. The role of intraspecific hybridization in the evolution of invasiveness: A case study of the ornamental pear tree Pyrus calleryana. Biol. Invasions 11:1107-1119.

Czarnecki, D., Z. Deng, and D.G. Clark. 2008. Assessment of ploidy levels, pollen viability, and seed production of Lantana camara cultivars and breeding lines. HortScience 43:1195 [Abstract].

Dehnen-Schmutz, K., J. Touza, C. Perrings, and M. Williamson. 2007. A century of the ornamental plant trade and its impact on invasion success. Divers. Distrib. 13:527-534.

Ebeling, S.K., I. Hensen, and H. Auge. 2007. The invasive shrub Buddleja davidii performs better in its introduced range. Divers. Distrib. 14 225-233.

Fedorov, A. 1974. Chromosome numbers of flowering plants. Reprint ed. Otto Koeltz Science, Koenigstein, West Germany.

Florida Exotic Pest Plant Council. 2007. Florida exotic pest plant council's 2007 list of invasive plant species. 5 June 2009. <http://www.fleppc. org/list/07list_brochure.pdf $>$.

Forcella, F., J.T. Wood, and S.P. Dillon. 1986. Characteristics distinguishing invasive weeds within Echium (bugloss). Weed Res. 26:351364.

Fox, A.M., D.R. Gordon, J.A. Dusky, L. Tyson, and R.K. Stocker. 2008. Institute of Food and Agricultural Sciences (IFAS) assessment of non-native plants in Florida's natural areasStatus assessment. 5 June 2009. < http://plants. ifas.ufl.edu/assessment/pdfs/concl_genus.pdf > .

Fox, A.M., D.R. Gordon, and R.K. Stocker. 2003 Challenges of reaching consensus on assessing which non-native plants are invasive in natural areas. HortScience 38:1-13.

Gann, G.D., K.A. Bradley, and S.W. Woodmansee. 2008. The floristic inventory of south Florida. Online database. The Institute for Regional Conservation. 15 May 2009. <http://regional conservation.org/ircs/database/site/Conservation Areas.asp $>$.

Gilman, E.F. 2007. Stachytarpheta jamaicensis blue porterweed. University of Florida Institute of Food and Agricultural Sciences (IFAS) Fact Sheet, FPS-559. 5 June 2009. <http://edis.ifas. ufl.edu/FP559>.

Groves, R., R. Boden, and M. Lonsdale. 2005. Jumping the garden fence: Invasive garden 
plants in Australia and their environmental and agricultural impacts. Commonwealth Scientific and Industrial Research Organization (CSIRO) report prepared for World Wildlife Fund (WWF)-Australia. WWF-Australia, Sydney, Australia.

Hammer, R. 1994. Plant profile: The so-called porterweeds. The Tillandsia, July-August Florida Native Plant Society.

Harrington, R.A., R. Kujawski, and H.D.P. Ryan. 2003. Invasive plants and the green industry. J. Arboriculture 29:42-47.

Hartmann, H.T., D.E. Kester, F.T. Davies, Jr., and R.L. Geneve. 2002. Plant propagation principles and practices. 7th Ed. Prentice Hall, Upper Saddle River, NJ.

Hodges, A.W. and J.J. Haydu. 2006. Economic impacts of the Florida Environmental Horticulture Industry in 2005. Food and Resource Economics Report, FE675, University of Florida, Gainesville. 12 Aug. 2008. <http:// economicimpact.ifas.ufl.edu $>$.

Langeland, K.A. and K. Craddock Burks. 1998. Identification and biology of non-native plants in Florida's natural areas. University of Florida, Gainesville, FL.

Li, Y., Z. Cheng, W.A. Smith, D.R. Ellis, Y. Chen, X. Zheng, Y. Pei, K. Luo, D. Zhao, Q. Yao, H. Duan, and Q. Li. 2004. Invasive ornamental plants: Problems, challenges, and molecular tools to neutralize their invasiveness. Crit. Rev. Plant Sci. 23:381-389.

Mack, R.N. and M. Erneberg. 2002. The United States naturalized flora: Largely the product of deliberate introductions. Ann. Mo. Bot. Gard. 89:176-189.

Mandák, B. 2003. Germination requirements of invasive and non-invasive Atriplex species: A comparative study. Flora 198:45-54.

Munir, A.A. 1992. A taxonomic revision of the genus Stachytarpheta Vahl (Verbenaceae) in Australia. J. Adelaide Botanic Garden 14:133-168.

Niemiera, A.X. and B. Von Holle. 2009. Invasive plant species and the ornamental horticulture industry. In: Inderjit, A. (ed.). Management of invasive weeds. Springer Science, Dordrecht, The Netherlands.

Pacific Island Ecosystems at Risk. 2007. Plant threats to pacific ecosystems. 12 Aug. 2008. $<$ http://www.hear.org/pier/threats.htm>.

Parker, C., B.P. Caton, and L. Fowler. 2007. Ranking nonindigenous weed species by their potential to invade the United States. Weed Sci. 55:386-397.
Pemberton, R.W. and H. Liu. 2009. Marketing time predicts naturalization of horticultural plants. Ecology 90:69-80.

Perrins, J., M. Williamson, and A. Fitter. 1992. Do annual weeds have predictable characters? Acta Oecol. 13:517-533.

Peters, J. 2000. Tetrazolium testing handbook, contribution No. 29 to the handbook on seed testing. Association of Official Seed Analysts, Las Cruces, NM.

Peters, N.C.B. 1982. The dormancy of wild oat seed (Avena fatua L.) from plants grown under various temperature and soil moisture conditions. Weed Res. 22:205-212.

Pyšek, P. and D.M. Richardson. 2007. Traits associated with invasiveness in alien plants: Where do we stand? Ecological studies. In: Nentwig, W. (ed.). Biological invasions. Springer-Verlag, Berlin, Heidelberg, Germany.

Ranney, T.G. 2004. Population control: Developing non-invasive nursery crops. Combined Proc. Intl. Plant Propagators' Soc. 54:604-607.

Reichard, S.H. and C.W. Hamilton. 1997. Predicting invasions of woody plants introduced into North America. Conserv. Biol. 11:193-203.

Reichard, S.H. and P. White. 2001. Horticulture as a pathway of invasive plant introductions in the United States. Bioscience 51:103-113.

Rejmánek, M. 2000. Invasive plants: Approaches and predictions. Austral Ecol. 25:497-506.

Sanders, R.W. 2001. The genera of Verbenaceae in the southeastern United States. Harv. Pap. Bot. 5:303-358.

Schierenbeck, K.A. and N.C. Ellstrand. 2009. Hybridization and the evolution of invasiveness in plants and other organisms. Biol. Invasions 11:1093-1105.

Schmitz, D. 2009. Florida Fish and Wildlife Conservation Commission (FWC) Invasive Plant Management Research Program Newsletter. 15 May 2009. <http://myfwc.com/docs/Wildlife Habitats/InvasivePlants_Researchnewsletter09. pdf $>$.

Susko, D.J., J.P. Mueller, and J.F. Spears. 1999. Influence of environmental factors on germination and emergence of Pueraria lobata. Weed Sci. 47:585-588.

U.S. Department of Agriculture. 2003. U.S. National Arboretum 'web version' of the U.S. Department of Agriculture Plant Hardiness Zone Map. USDA Miscellaneous Publication No. 1475, issued Jan. 1990. 25 Nov. 2008 $<$ http://www.usna.usda.gov/Hardzone/ushzmap. html $>$.
U.S. Department of Agriculture. 2008. The PLANTS database. Version 3.5. National Plant Data Center, Baton Rouge, LA. 15 May 2008. $<$ http://plants.usda.gov/java/nameSearch? keywordquery $=$ pennisetum + setaceum $\&$ mode $=$ sciname\&submit. $\mathrm{x}=13 \&$ submit. $\mathrm{y}=8>$.

Viloria, Z. and J.W. Grosser. 2005. Acid citrus fruit improvement via interploid hybridization using allotetraploid somatic hybrid and autotetraploid breeding parents. J. Amer. Soc. Hort. Sci. 130:392-402.

Wagner, W.L., D.R. Herbst, and S.H. Sohmer. 1999. Stachytarpheta. Manual of the flowering plants of Hawaii, revised edition. Vol. 2. University of Hawaii Press, Honolulu, HI p. 1321-1324.

Williamson, M.H. and A. Fitter. 1996. The characters of successful invaders. Biol. Conserv. 78:163-170.

Wilson, S.B. and G.W. Knox. 2006. Landscape performance, flowering, and seed viability of fifteen Miscanthus sinensis taxa grown in northern and southern Florida. HortTechnology 24:137-142.

Wilson, S.B., M. Thetford, L.K. Mecca, and J.S. Raymer. 2004a. Evaluation of 14 Buddleja taxa grown in western and southern Florida: I. Visual quality, growth and development. HortTechnology 14:605-612.

Wilson, S.B., M. Thetford, L.K. Mecca, J.S. Raymer, and J. Gersony. 2004b. Evaluation of 14 Buddleja taxa grown in western and southern Florida: II. Seed production and germination. HortTechnology 14:612-618.

World Wildlife Fund Australia. 2006. National list of naturalized invasive and potentially invasive garden plants. 15 May 2009. <http://wwf.org. au/publications/ListInvasivePlants $>$.

Wunderlin, R.P. and B.F. Hansen. 2009a. Atlas of Florida vascular plants: Stachytarpheta cayennensis [S.M. Landry and K.N. Campbell (application development), Florida Center for Community Design and Research]. Institute for Systematic Botany, Univ. of South Florida, Tampa. 5 June 2009. <http://www.florida. plantatlas.usf.edu/Plant.aspx?id=215>.

Wunderlin, R.P. and B.F. Hansen. 2009b. Atlas of Florida vascular plants: Stachytarpheta $\times$ intercedens [S.M. Landry and K.N. Campbell (application development), Florida Center for Community Design and Research]. Institute for Systematic Botany, Univ. of South Florida, Tampa. 5 June 2009. <http://www.florida. plantatlas.usf.edu/Plant.aspx?id=4252>. 